\title{
STRATEGIES FOR IMMOBILIZATION OF BIOACTIVE ORGANIC MOLECULES ON TITANIUM IMPLANT SURFACES - A REVIEW
}

Ivan V. Panayotov ${ }^{1}$, Boyan S. Vladimirov ${ }^{2 *}$, Pierre-Yves C. Dutilleul ${ }^{1}$, Bernard Levallois ${ }^{1}$, Frédéric Cuisinier ${ }^{1}$ ${ }^{1}$ EA4203 Laboratoire de Bioingénierie et Nanoscience, Université de Montpellier, Montpellier, France; ${ }^{2}$ Department of Maxillofacial Surgery, Faculty of Dental Medicine, Medical University, Plovdiv, Bulgaria

\section{СТРАТЕГИИ ДЛЯ ИММОБИЛИЗАЦИИ БИОЛОГИЧЕСКИ АКТИВНЫХ МОЛЕКУЛ НА ПОВЕРХНОСТИ ТИТАНОВЫХ ИМПЛАНТАТОВ - ЛИТЕРАТУРНЫЙ ОБЗОР}

Иван В. Панайотов ${ }^{1}$, Боян С. Владимиров ${ }^{2 *}$, Пьер-Ив К. Дьотийол ${ }^{1}$, Бернар Льовалоа ${ }^{1}$, Фредерик Кюизиние ${ }^{1}$

${ }^{1}$ ЕА4203 Лаборатория биоинженерии и нанонаук, Университет Монпелье, Монпелье, Франция; ${ }^{2}$ Кафедра челюстно-лицевой хирургии, Факультет стоматологии, Медицинский университет, Пловдив, Болгария

\begin{abstract}
Numerous approaches have been used to improve the tissue-implant interface of titanium (Ti) and titanium alloy $\left(\mathrm{Ti}_{6} \mathrm{Al}_{4} \mathrm{~V}\right)$. They all aim at increasing cell migration and attachment to the metal, preventing unspecific protein adsorption and improving post-implantation healing process. Promising methods for titanium and titanium alloy surface modification are based on the immobilization of biologically active organic molecules. New and interesting biochemical approaches to such surface modification include layer-by-layer deposition of polyelectrolyte films, phage display-selected surface binding peptides and self-assembled DNA monolayer systems. The present review summarizes the scientific information about these methods, which are at in vitro or in vivo development stages, and hopes to promote their future application in dental implantology and in oral and maxillofacial surgery.
\end{abstract}

Key words: titanium implants, surface functionalization, polyelectrolyte multi-layers, metal-binding peptides, DNA monolayers

Folia Medica 2015; 57(1): 11-18

Copyright (C) 2015 Medical University, Plovdiv

\begin{abstract}
РЕЗЮМЕ
Существует большое разнообразие подходов для усовершенствования поверхности титана (Ті) и титанового сплава - $\mathrm{Ti}_{6} \mathrm{Al}_{4} \mathrm{~V}$, с целью улучшения их взаимодействия с тканью человеческого тела. Данные подходы нацелены на стимулирование клеточной миграции и прикрепления к металлу, на воспрепятствование адсорбции неспецифических белков и на улучшение оздоровительного процесса после имплантирования. Среди наиболее перспективных разработок выделяются методы модификации поверхности титана и титановых сплавов, основанных на иммобилизации биологически активных органических молекул. Новые и интересные биохимические подходы с целью подобной модификации поверхностей включают послойное нанесение полиэлектролитных мультислоев, применение связывающихся с поверхностью пептидов, выделенных при помощи фагового дисплея и самооформляющихся ДНК однослойных систем. Настоящий обзор обобщает научную информацию по данным методам, находящихся на стадии разработки in-vitro или in-vivo и ставит перед собой цель стимулировать усилия по будущему применению в дентальной имплантологии, в области оральной и челюстно-лицевой хирургии.
\end{abstract}

Ключевые слова: титановые имплантаты, функционализация поверхностей, полиэлектролитные мультислои, связывающие металл пептиды, ДНК единичные слои

Folia Medica 2015; 57(1): 11-18

(C) 2015 Все права защищены. Медицинский университет, Пловдив

\footnotetext{
Article's history: Received: 30 Sept 2014; Received in a revised form: 21 Jan 2015; Accepted: 1 Feb 2015

*Correspondence and reprint request to: B. Vladimirov, Department of Maxillofacial Surgery, Faculty of Dental Medicine,

Medical University - Plovdiv; Mobile: +359 898690 959: E-mail: boyanvlad@yahoo.com

3, Hristo Botev Blvd, 4002 Plovdiv, Bulgaria
} 


\section{INTRODUCTION}

Titanium (Ti) is the most widely used material for dental implants. Titanium is used mainly as it is, commercially pure (Grade 4) titanium, or as a titanium alloy $\left(\mathrm{Ti}_{6} \mathrm{Al}_{4} \mathrm{~V}\right.$; Grade 5 titanium). ${ }^{1}$ The advantages of these materials are attributed to their mechanical properties and biocompatibility which make them better suited to replace teeth compared to other metallic biomaterials. They are resistant to corrosion and demonstrate bio-inert behavior in $v i v o^{2}$. The surface of titanium and titanium alloy implants is always covered by a passive $\mathrm{TiO}_{2}$ layer (with a thickness of several nanometers), which is responsible for their excellent biological properties. However, the surface properties of titanium materials have some shortcomings with regard to their abilities for tissue integration - and surface modifications methods have been developed. A common classification of methods for surface modification of titanium implant devices for biomedical applications is presented in Table $1 .^{3}$

Table 1. Surface modification techniques for implants based on titanium and its alloys

\begin{tabular}{|c|c|c|c|}
\hline & Method & Surface & Objective \\
\hline 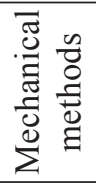 & $\begin{array}{l}\text { Machining } \\
\text { Grinding } \\
\text { Polishing } \\
\text { Blasting }\end{array}$ & $\begin{array}{l}\text { Rough or smooth surface } \\
\text { formed by subtraction pro- } \\
\text { cess }\end{array}$ & $\begin{array}{l}\text { Produce specific surface topographies; } \\
\text { clean and roughen surface; improve } \\
\text { adhesion in bonding }\end{array}$ \\
\hline \multirow{6}{*}{ 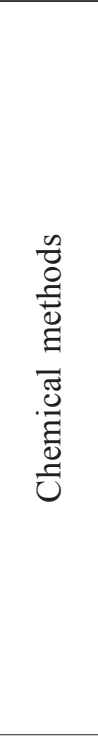 } & Acid treatment & $\begin{array}{l}<10 \mathrm{~nm} \text { of surface oxide } \\
\text { layer }\end{array}$ & $\begin{array}{l}\text { Remove oxide scales and contami- } \\
\text { nation }\end{array}$ \\
\hline & Alkaline treatment & $\begin{array}{l}\sim 1 \mathrm{~mm} \text { of sodium titan- } \\
\text { ate gel }\end{array}$ & $\begin{array}{l}\text { Improve biocompatibility, bioactivity } \\
\text { or bone conductivity }\end{array}$ \\
\hline & Hydrogen peroxide treatment & $\begin{array}{l}\sim 5 \mathrm{~nm} \text { of dense inner oxide } \\
\text { and porous outer layer }\end{array}$ & $\begin{array}{l}\text { Improve biocompatibility, bioactivity } \\
\text { or bone conductivity }\end{array}$ \\
\hline & Sol-gel & $\begin{array}{l}\sim 10 \mathrm{~mm} \text { of thin film, such } \\
\text { as calcium phosphate, } \mathrm{TiO}_{2} \\
\text { and silica }\end{array}$ & $\begin{array}{l}\text { Improve biocompatibility, bioactivity } \\
\text { or bone conductivity }\end{array}$ \\
\hline & Anodic oxidation & $\begin{array}{l}\sim 10 \mathrm{~nm} \text { to } 40 \mathrm{~mm} \text { of } \\
\mathrm{TiO}_{2} \text { layer, adsorption and } \\
\text { incorporation of electrolyte } \\
\text { anions }\end{array}$ & $\begin{array}{l}\text { Produce specific surface topographies; } \\
\text { improve corrosion resistance; improve } \\
\text { biocompatibility, bioactivity or bone } \\
\text { conductivity }\end{array}$ \\
\hline & Chemical Vapor Deposition & $\begin{array}{l}\sim 1 \mathrm{~mm} \text { of } \mathrm{TiN}, \mathrm{TiC}, \mathrm{TiCN}, \\
\text { diamond and diamond-like } \\
\text { carbon thin film }\end{array}$ & $\begin{array}{l}\text { Improve wear resistance, corrosion } \\
\text { resistance and blood compatibility }\end{array}$ \\
\hline 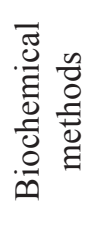 & $\begin{array}{l}\text { Silanization, } \\
\text { photochemistry, } \\
\text { self-assembled monolayers (SAMs), } \\
\text { polyelectrolyte multilayers (PEMs), } \\
\text { self-assembly DNA systems }\end{array}$ & $\begin{array}{l}\text { Deposition of various coat- } \\
\text { ings on titanium surfaces } \\
\text { Immobilization of biological } \\
\text { active molecules }\end{array}$ & $\begin{array}{l}\text { Induce specific cell and tissue re- } \\
\text { sponse by means of surface-immo- } \\
\text { bilized peptides, proteins, or growth } \\
\text { factors }\end{array}$ \\
\hline \multirow{4}{*}{ 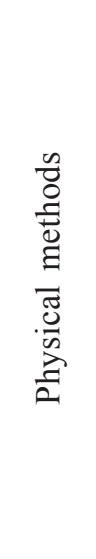 } & $\begin{array}{l}\text { Thermal spray (Flame spray Plasma } \\
\text { spray) HVOF (high } \\
\text { velocity oxy-fuel) spraying } \\
\text { DGUN(Detonation-gun spraying) }\end{array}$ & $\begin{array}{l}\sim 30 \text { to } 200 \mathrm{~mm} \text { coatings, } \\
\text { such as titanium, } \mathrm{HA} \text {, cal- } \\
\text { cium silicate, } \mathrm{Al}_{2} \mathrm{O}_{3}, \mathrm{ZrO}_{2} \text {, } \\
\mathrm{TiO}_{2}\end{array}$ & $\begin{array}{l}\text { Improve wear resistance, corrosion } \\
\text { Plasma spray resistance and biologi- } \\
\text { cal properties }\end{array}$ \\
\hline & $\begin{array}{l}\text { Physical vapor deposition (PVD) : } \\
\text { Evaporation ; Ion plating ; Sput- } \\
\text { tering }\end{array}$ & $\begin{array}{l}\sim 1 \mathrm{~mm} \text { of } \mathrm{TiN}, \mathrm{TiC}, \mathrm{TiCN}, \\
\text { diamond and diamond-like } \\
\text { carbon thin film }\end{array}$ & $\begin{array}{l}\text { Improve wear resistance, corrosion } \\
\text { resistance and blood compatibility }\end{array}$ \\
\hline & $\begin{array}{l}\text { Ion implantation and deposition : } \\
\text { Beam-line ion implantation ; PIII }\end{array}$ & $\begin{array}{l}\sim 10 \mathrm{~nm} \text { of surface modified } \\
\text { layer and/or } \sim \mu \mathrm{m} \text { of thin film }\end{array}$ & $\begin{array}{l}\text { Modify surface composition; improve } \\
\text { wear, corrosion resistance, and bio- } \\
\text { compatibility }\end{array}$ \\
\hline & Glow discharge plasma treatment & $\begin{array}{l}\sim 1 \mathrm{~nm} \text { to } 100 \mathrm{~nm} \text { of surface } \\
\text { modified layer }\end{array}$ & $\begin{array}{l}\text { Clean, sterilize, oxide, nitride surface; } \\
\text { remove native oxide layer }\end{array}$ \\
\hline
\end{tabular}


Implant surface modifications by methods based on immobilization of biologically active organic molecules on $\mathrm{Ti}$ and $\mathrm{Ti}_{6} \mathrm{Al}_{4} \mathrm{~V}$ surfaces have attracted much interest recently. The aim of such modifications is to increase cell migration and attachment to the substrate, to prevent unspecific protein adsorption and to improve the healing process after implantation. As regards dental implants, these surface modification methods could be used to: 1) increase the osseointegration properties of the intraosseous part of the dental implant; 2) promote the epithelial cell adhesion to the trans-gingival part of the implant; and 3) inhibit the bacterial colonization of the surface.

Although organic bioactive molecules such as surface-immobilized peptides, proteins, or growth factors show promising capabilities for promotion of implant surface interactions with the host tissues, their immobilization on the implant surface requires complex physicochemical methods. Adsorption, covalent binding, electrochemical techniques (anodization and electro-refining $)^{2}$ are most frequently used. These methods involve specific chemical or electrochemical treatment of the implant surface which is easily applicable in laboratory settings, but their clinical improvement is still under evaluation as a number of problems have to be overcome.

The aim of this review was to describe the biochemical methods for titanium surface functionalization making a critical analysis of the strategies for immobilization of bioactive molecules onto the surface. We will mainly focus on five most recent and promising methods: 1) direct protein adsorption, 2) self-assembling monolayer (SAMs) systems for protein immobilization, 3) layer-by-layer build-up of polyelectrolyte films (PEMs) for protein immobilization, 4) phage display selection of specific surface binding peptides, used then as materialspecific linker for small bio-active molecules; and 5) self-assembled DNA monolayer systems. All these methods have been already described in vitro and some of them - in vivo studies.

\section{DIRECT ADSORPTION OF EXTRACELLULAR MATRIX AND PLASMA PROTEINS FOR Ti FUNC- TIONALIZATION}

A large number of in vitro and in vivo studies reported application of biologically active protein molecules directly on implant surfaces. Molecules like plasma and extracellular matrix proteins (laminin, fibronectin, vitronectin, type I collagen, osteogenin, bone sialo protein), growth factors (interleukin, IGF, FGF-2, PDGF-BB) or small pep- tide sequences, derivatives from different bioactive proteins, which could be recognized by cell surface receptors have been applied. Sela et al. described an in vitro study on the adsorption of four plasma proteins (albumin, IgG, fibronectin and fibrinogen) on machined, acid etched and blasted Ti surfaces. ${ }^{4}$ The acid etched-blasted surfaces assured better adhesion for all tested proteins. Schliephake et al. demonstrated that organic coating of titanium screw implants enhanced peri-implant bone formation in a dog model. ${ }^{5}$ The authors evaluated the following types of implant surfaces: (1) implants with machined titanium surface, (2) implants coated with collagen I, (3) implants with collagen I and cyclic RGD peptide coating (Arg-Gly-Asp) at low and high concentrations. They found that the periimplant bone formation was significantly increased in all coated implants in comparison to machined surfaces for two observation periods ( 1 month and 3 months). Liu et al. used bone morphogenic protein-2 (BMP-2) to increase the osteoconductive properties of the intraosseus part of dental implants in a pig model. ${ }^{6}$ The BMP-2 coated surfaces were compared with naked titanium surfaces and calcium-phosphate coated surfaces. The BMP-2 was applied directly on the titanium surface or it was incorporated in a calcium coating during the inorganic layer deposition. The authors reported that the osteoconductivity of implant surfaces was significantly modulated by BMP-2 and the modality of its delivery. Finally, Min et al. investigated the attachment and osteoblastic gene expression of osteoblast-like cells seeded onto a laminin-derived functional peptide (Ln2-P3) coated Ti implant surface using the human osteosarcoma (HOS) cell line. ${ }^{7}$ Ln2-P3 is a laminin-derived functional peptide having the DLTIDDSYWYRI sequence. It was deposited on three different SLA (sandblasted with large grit and acid etched) surfaces, anodized Ti surface and calcium phosphorus (Ca-P) coated titanium surface. The authors reported that Ln2-P3 peptide improved the biocompatibility of the implant surface and facilitated bone cell attachment.

\section{SELF-ASSEMBLING MONOLAYERS (SAMs) AS PEPTIDE SURFACE CARRIERS}

Self-assembly of monolayers (SAMs) are layers covalently bonded on the surface - they have been used for immobilization of peptide chains on implant surfaces via interaction between anchor groups of the molecules and specific interaction sites on the surface. ${ }^{2}$ The method was also applied for immobilization of biologically active peptides on titanium implant surfaces. This SAMs technique 
was adapted for titanium-based biomaterials by Huang et al. to improve the integration of dental implants into surrounding bone. ${ }^{8}$ After pre-coating the titanium implant with gold, the surfaces were modified with RGD-peptide and the enhanced osteoconductive capacities of the implants have been observed in vitro. The most common approach to studying and controlling the orientation of extracellular matrix proteins is the use of thiol SAMs with differing terminal functionalities to create surface coatings with tunable hydrophobic and electrostatic properties. ${ }^{9}$ Ratner, Jiang and co-workers used these surfaces to achieve adsorption of complete osteopontin (OPN), which contains RGD among other domains ${ }^{10}$ and a fibronectin (FN) fragment FNIII $10 .{ }^{11}$ However, these two examples of surface functionalization were not performed on titanium substrates. Schuler et al. (2006) ${ }^{12}$ immobilized the RGD bioactive peptide sequence via a non-fouling poly(L-lysine)-graft-poly(ethylene glycol) (PLL-gPEG) molecular assembly system, which allowed exploitation of specific cell-peptide interactions even in presence of serum. The authors tested the surfaces for three different types of cell lines: porcine epithelial cells (EC), swiss Balb/c 3 T3 fibroblasts (FB) and rat calvarial osteoblasts (OB). Coating with the non-fouling PLL-g-PEG polymer reduced cell attachment and footprint areas, whereas the immobilization of the RGD-peptide sequence restored cell attachment and footprint areas to levels typically found on (unmodified) titanium surfaces. Scheideler et al. covalently coupled titanium surfaces with human fibronectin via salinization and use of an anthraquinone linker. ${ }^{13}$ Coupling efficiency was related to the irradiation time used for photochemical coupling of the UV-activated anthraquinone to the silanized Ti surface. Keratinocyte adhesion, platelet interactions and pellicle formation were studied. On the anthraquinone-coupled fibronectin coatings cell adhesion and spreading of human keratinocytes were significantly enhanced.

\section{POLYELECTROLYTE MULTILAYERS FOR PRO- TEIN/PEPTIDE IMMOBILIZATION}

Another approach for immobilization of proteins or peptide molecules on titanium implant surfaces uses electrostatically (layer by layer) bound layers. The layer-by-layer (LbL) film deposition method consists of alternate adsorption of oppositely charged polyelectrolytes that auto-assemble, leading to the formation of polyelectrolyte multilayer (PEM) films. ${ }^{14}$ Protein adsorption onto polyelectrolyte films has been described, evidencing PEMs as promising candidates for biological applications. ${ }^{15}$ PEMs combined with biomolecules could mimic the natural extracellular matrix and provide good osteoconductivity. Hence the LbL method has been applied for functionalization of $\mathrm{Ti}$ surfaces and immobilization of bioactive organic molecules on such surfaces has been performed. Several studies aimed to increase cell adhesion on PEM films by coating the final layer with adhesion-promoters. ${ }^{16}$ These studies have been well reviewed by Boudou et al. ${ }^{16}$ and they are presented in Table 2 .

Only two of these bioactive peptides and proteins (marked with *) were immobilized by means of PEM films on a Ti surface for dental applications and one of them was tested in vivo. Halthur et al. immobilized enamel matrix derivate (EMD) protein using poly(L-glutamic acid) (PGA) and poly(L-lysine) (PLL) multilayers on silica and titanium surfaces. ${ }^{17}$ The formed polypeptide-EMD films were able to trigger cell response and induce biomineralization. Werner et al. applied a similar approach to convert the bio-inert titanium material to a bioactive surface that promotes epithelial cell adhesion. ${ }^{18}$ They used a laminin-5-derived adhesion peptide coupled on a PLL/PGA thin multilayer for functionalization of "porous titanium" structure in the gingival part of the dental implant. By means of both in vitro and in vivo experiments the authors studied the short-term cell adhesion and cell proliferation. In another study Schultz et al. coupled the alpha-melanocyte-stimulating hormone (alpha-MSH) to the PGA ending surface of the (PLL/PGA) film to create biologically active coatings for titanium tracheal prostheses. ${ }^{19}$ The results were tested both in vitro and in vivo. Histological analysis at 1 month after implantation showed a fibroblast colonization of the periprosthetic side and the formation of a respiratory epithelium on the endo-luminal side of the surface modified implant. Cai et al. used the layer-by-layer self-assembly technique, based on the polyelectrolyte-mediated electrostatic adsorption of chitosan (Chi) and gelatin (Gel) on thin titanium surface. ${ }^{20}$ Cell proliferation and cell viability of osteoblasts on LbL-modified titanium were better than those on bare Ti surfaces. Few years later Chua et al. showed that the adhesion and proliferation of osteoblasts on titanium surfaces could be improved by using polyelectrolyte multilayers of chitosan and hyaluronic acid coupled with celladhesion promoting arginine-glycine-aspartic acid (RGD) peptide. ${ }^{21}$ An antibacterial effect of the PEM (without RGD peptide) was also observed. Muller $\mathrm{S}$ et al. modified the surface of porous tita- 
Table 2. Bioactive molecules immobilized on surfaces by means of PEM films ${ }^{16}$

\begin{tabular}{|c|c|c|}
\hline $\begin{array}{l}\text { Bioactive molecule: } \\
\text { protein/growth factor }\end{array}$ & PEM film & Main findings \\
\hline $\begin{array}{l}\text { *enamel matrix derivate } \\
(\text { EMD) }\end{array}$ & (PLL/PGA)-PGA & $\begin{array}{l}\text { Immobilization of enamel matrix derivate (EMD) both on top } \\
\text { and within PEM films }\end{array}$ \\
\hline *laminin-derived peptide & (PLL/PGA) & $\begin{array}{l}\text { In vitro, the films enhance epithelial cell } \\
\text { colonization and proliferation; Specific formation of adhesive } \\
\text { structures (hemidesmosomes) in the presence of the peptide }\end{array}$ \\
\hline Protein A & (PLL/PGA) & Expression of TNF- $\alpha$ in THP-1 phagocytic cells \\
\hline $\begin{array}{l}\text { Brain Derived Neurotroph- } \\
\text { ic Factor Semaphorin } 3 \mathrm{~A}\end{array}$ & $(\mathrm{PSS} / \mathrm{PAH})$ & Increased neuronal activity \\
\hline$\alpha \mathrm{FGF} / \beta \mathrm{FGF}$ & $\begin{array}{l}\text { FGF/heparin } \\
\text { CSA/FGF }\end{array}$ & Enhanced expression of collagen I and IL-6 \\
\hline FGF or IPM & (PLL/CSA) & Specific differentiation of embryonic stem cells \\
\hline BMP-2/TGF 3 & (PLL/PGA) & Specific differentiation of embryonic stem cells \\
\hline BMP4/noggin & $(\mathrm{PLL} / \mathrm{PGA})$ & Inhibition or induction of cell death in tooth development \\
\hline rhBMP-2 & $\begin{array}{l}\text { (PLL/HA) } \\
\text { X-linked films }\end{array}$ & Dose-dependent differentiation of myoblasts into osteoblasts \\
\hline VEGF & (PSS/PAH) & $\begin{array}{l}\text { Pro-angiogenic prosthetic coating } \\
\text { Specific activation of intra-cellular pathway (VEGF receptor } \\
\text { and the MAPK ERK } 1 / 2 \text { ) }\end{array}$ \\
\hline alpha-MSH & (PLL/PGA) & $\begin{array}{l}\text { Fibroblastic colonization of the periprosthetic site and respira- } \\
\text { tory epithelium on the internal side }\end{array}$ \\
\hline
\end{tabular}

nium implants with PEM films functionalized with vascular endothelial growth factor (VEGF). ${ }^{22}$ Four different PEM films were investigated: (PAH/PSS) $(\mathrm{PAH} / \mathrm{PSS})_{4} / \mathrm{PAH},(\mathrm{PLL} / \mathrm{PGA})_{4}$ and $(\mathrm{PLL} / \mathrm{PGA})_{4} /$ PLL. The $(\mathrm{PAH} / \mathrm{PSS})_{4}$ coating was selected as the most useful film for VEGF adsorption. The effects induced by $(\mathrm{PAH} / \mathrm{PSS})_{4} / \mathrm{VEGF}$ films were associated with specific activation of VEGFR2 receptors and downstream induced kinases (MAPK) ERK1/2. Zhang et al. proposed a different concept. ${ }^{23}$ They aimed to build a biocompatible and antibacterial surface on the titanium alloy. Firstly, alginate was modified by dopamine, which led to synthesis of DAL (dopamine-alginate complex). The surface of titanium was coated via layer-by-layer technique by
DAL/Chi multilayers and then the samples were immersed in $\mathrm{AgNO}_{3}$ solution resulting in the final $\mathrm{AgNO}_{3}$-DAL/Chi assembly. The antibacterial property and cytotoxicity of titanium alloy coated with $\mathrm{AgNO}_{3}$-containing polyelectrolyte was demonstrated.

\section{METAL BINDING PEPTIDES FOR IMMOBILI- ZATION OF BIOACTIVE MOLECULES ON Ti- IMPLANT SURFACES}

Both previously described methods (SAMs and PEMs) result in the creation of a synthetic layer on the titanium surface, which is nonspecifically bound to the material. PEM films could also be considered to represent an extracellular matrix for the adhered molecules. At the same time surface 
characteristics like hydrophobicity, charge, stiffness and roughness could be controlled using this methods. One disadvantage of these two systems is that the created surface coating could influence by itself the cell adhesion and proliferation onto the surface and decrease the effect of the immobilized specific molecule.

A principally new approach for peptide immobilization on titanium surfaces has been proposed in the past ten years. The selection of titanium binding 12-mer and 7-mer peptides from phage display libraries has become a popular affinity biopanning method. In 2003 Sano et al. obtained a Ti-surface binding 12-mer peptide by phage display methodology, which was named TBP-1 (RKLPDAPGMHTW) ${ }^{24}$ Using the same method Liu et al. selected a small amino acid sequence revealing a high affinity to commercially used titanium substrates ${ }^{25}$ and it was suggested that the sequence has a strong affinity for the $\mathrm{TiO}_{2}$ layer formed on the implant surface. Estephan et al. investigated the surface active properties of another 12-mer peptide binding to $\mathrm{Ti}$ and $\mathrm{Ti}_{6} \mathrm{Al}_{4} \mathrm{~V}$ surfaces. ${ }^{26}$ All these authors did not consider the use of these surface binding peptides for immobilization of bioactive molecules. However, searching to promote titanium surface endothelization, Meyer et al. proposed to attach the 12-mer titanium binding peptide to the RGD sequence. The authors demonstrated better adhesion and proliferation of endothelial cells on titanium functionalized with the peptide-RGD binder. ${ }^{27}$ In 2013, Yazici $\mathrm{H}$ et al. employed the same approach to bind phage display selected titanium binding peptide (TiBP) and Arg-Gly-Asp-Ser
(RGDS) sequence to improve fibroblast cell adhesion on commercial grade Ti surface. ${ }^{28}$ Titanium and titanium compound binding sequences found in the literature are summarized in Table 3 . Indeed, the most commonly used bio-active peptide sequence to promote cell adhesion on different surfaces is the RGD (-arginine-glycine-aspartate-) sequence. It is found in most extracellular matrix (EMC) proteins such as fibronectin, laminin, and vitronectin influencing cell adhesion, mobility, proliferation, and cell survival and has been shown to bind approximately half of the 24 known human integrins. ${ }^{9}$ Table 4 summarizes various amino acid sequences used for promoting cell bioactivity that could be grafted on titanium and titanium alloy surfaces. The use of synthetic bi-functional peptides for biomaterial surface functionalization allows, on one hand, targeting specific surface adhesion sites and on the other hand - selecting the cells which would adhere to them. However, the exact mechanism of cell adhesion to the peptide-modified surfaces is not clear. The in vivo survival of such bi-functional peptide coatings also needs to be further studied.

\section{DNA MONOLAYER SYSTEMS}

Recently a new method of surface modification for titanium and its alloys with bioactive molecules has been developed. Nucleic acid single strands were deposited electrochemically via their termini by growing an oxide layer on $\mathrm{Ti}_{6} \mathrm{Al}_{7} \mathrm{Nb}$ anodically. ${ }^{29}$ The immobilized single DNA strands were accessible for subsequent hybridization with complementary strands at physiological $\mathrm{pH}$. Then the hexapeptide

Table 3. Titanium binding peptides created by phage display technology and cell adhesion binding domains, which could induce cell adhesion on implant surfaces (Data from Seker UO, Demir HV. Material binding peptides for nanotechnology. Molecules 2011;16(2):1426-51)

\begin{tabular}{ll}
\hline \multicolumn{1}{c}{ Sequences } & \multicolumn{1}{c}{ Surfaces } \\
\hline RKLPDAPGMHTW & $\mathrm{Ti}, \mathrm{Si}, \mathrm{Ag}$ \\
SCSDCLKSVDFIPSSLASS & $\mathrm{Ti}$ \\
YPSAPPQWLTNT, STPLVTGTNNLM, QSGSHVTGDLRL, & $\mathrm{TiO}_{2}$ \\
LNAAVPFTMAGS & $\mathrm{TiO}_{2}$ coated stainless steal \\
ATWVSPY & $\mathrm{Ti}$ \\
RKKRTKNPTHKLGGGW, KSLSRHDHIHHHGGGW & $\mathrm{Ti}$ \\
TQHLSHPRYATKGGGW & $\mathrm{Ti}_{\text {Ti }} \mathrm{Al}_{4} \mathrm{~V}, \mathrm{HA}, \mathrm{GaN}, \mathrm{Co}, \mathrm{SiO}_{2}$, \\
SVSVGMKPSPRP & $\mathrm{Carbon}$ nanotubes \\
RPRENRGRERGL, SRPNGYGGSESS, VGRVTSPRPQGR & $\mathrm{Ti}$ grade 4 \\
\hline
\end{tabular}


Table 4. Amino-acid sequences derived from different biological molecules ${ }^{9}$

\begin{tabular}{ll}
\hline \multicolumn{1}{c}{ Sequences } & \multicolumn{1}{c}{ Biological Activity } \\
\hline YIGSR, IKVAV & Laminin-derived peptide sequences for adipose-derived stem cells \\
\hline RGD & 24 known human integrins \\
\hline GRGDS and WQPPRARI & $\begin{array}{l}\text { Worked best in promoting attachment, spreading, and proliferation of } \\
\text { human umbilical vein endothelial cells }\end{array}$ \\
\hline GFOGER (applied on Ti surface) & $\begin{array}{l}\text { Collagen-mimetic peptide, selectively promoting } \alpha 2 \beta 1 \text { integrin binding, } \\
\text { for osteoblastic differentiation }\end{array}$ \\
\hline WQPPRARI, SPPRRARVT & $\begin{array}{l}\text { Heparin binding peptides identified from fibronectin and heparin to bind } \\
\text { human pulmonary artery endothelial cell }\end{array}$ \\
\hline RRETAWA & $\begin{array}{l}\text { Motif binding the } \alpha 5 \beta 1 \text { integrin that promotes endothelial cell } \\
\text { (EC)-selective attachment }\end{array}$ \\
\hline $\begin{array}{l}\text { KPVSLSYRAPARFFESHVA } \\
\text { DTAYKDWPNLFREIR }\end{array}$ & $\begin{array}{l}\text { IKVAV and YIGSR containing peptides heparin sulfate binding motif to } \\
\text { bind osteoblast progenitor cells }\end{array}$ \\
\hline $\begin{array}{l}\text { DLTIDDSYWYRI } \\
\text { tested to Ti implants in vivo) }\end{array}$ & \begin{tabular}{l} 
Motif of the human laminin-2 a2 chain \\
\hline PPFLMLLKGSTR
\end{tabular} \\
\hline $\begin{array}{l}\text { Binds } \alpha 3 \beta 1 \text { domain of integrin receptors and promotes keratinocyte cell } \\
\text { adhesion }\end{array}$ \\
\hline SWELYYPLRANL & $\begin{array}{l}\text { Binds both E- and N-cad/Fc chimeric proteins of cadherin receptors of } \\
\text { epithelial cells }\end{array}$ \\
\hline
\end{tabular}

GRGDSP was immobilized on the functionalized surface to bind the integrin receptors of osteoblasts cells due to the presence of the RGD integrin recognition site. ${ }^{30}$ These results defined the nucleic acid self-organization as a promising tool for biosurface engineering of titanium implant materials. The DNA method is a completely new approach awaiting further in vitro and in vivo confirmation.

\section{CONCLUSIONS}

The present review has summarized the current bio-chemical methods for titanium surface functionalization. The common principle behind all the strategies has been the immobilization of organic bioactive molecules on the implant surface. The development of the various methods over the years has been based on the following approach: from "nonspecific surface coatings" toward "specific surface binding" molecules. The SAM systems have been replaced by polyelectrolyte multilayers because of the less toxic effect of the PEM films and the possibility for creation of an artificial synthetic matrix on the surface that could be used as a scaffold by the cells. On the other hand direct application of bi-functional bioactive molecules on the implant leads to direct cell-surface interaction.
Both the latter method and the DNA method are novel specific approaches awaiting further in vitro and in vivo confirmation. Each application field has specific requirements and therefore specific functionalization methods are needed. The methods reviewed above seem promising for surface functionalization by bioactive molecules of titanium and titanium alloy devices in dental implantology and maxillofacial surgery.

\section{REFERENCES}

1. Dohan Ehrenfest DM, Coelho PG, Kang BS, Sul YT, Albrektsson T. Classification of osseointegrated implant surfaces: materials, chemistry and topography. Trends Biotechnol 2010;28(4):198-206.

2. Beutner R, Michael J, Schwenzer B, Scharnweber D. Biological nano-functionalization of titaniumbased biomaterial surfaces: a flexible toolbox. J R Soc Interface 2010;7 Suppl 1:S93-S105.

3. Liu X, Chu PK, Ding C. Surface modification of titanium, titanium alloys, and related materials for biomedical applications. Materials Science and Engineering 2004;47:49-121.

4. Sela MN, Badihi L, Rosen G, Steinberg D, Kohavi D. Adsorption of human plasma proteins to modified titanium surfaces. Clin Oral Implants Res 2007;18(5):630-8.

5. Schliephake H, Scharnweber D, Dard M, Sewing A, 
Aref A, Roessler S. Functionalization of dental implant surfaces using adhesion molecules. J Biomed Mater Res B Appl Biomater 2005;73(1):88-96.

6. Liu Y, Enggist L, Kuffer AF, Buser D, Hunziker EB. The influence of BMP-2 and its mode of delivery on the osteoconductivity of implant surfaces during the early phase of osseointegration. Biomaterials 2007;28(16):2677-86.

7. Min SK, Kang HK, Jang DH, et al. Titanium surface coating with a laminin-derived functional peptide promotes bone cell adhesion. BioMed Research International 2013;2013:638348.

8. Huang H, Zhao Y, Liu Z, Zhang Y, Zhang H, Fu T, Ma X. Enhanced osteoblast functions on RGD immobilized surface. J Oral Implantol 2003;29(2):73-9.

9. Meyers SR, Grinstaff MW. Biocompatible and bioactive surface modifications for prolonged in vivo efficacy. Chemical reviews 2012;112(3):1615-32.

10. Liu L, Chen S, Giachelli CM, Ratner BD, Jiang S. Controlling osteopontin orientation on surfaces to modulate endothelial cell adhesion. J Biomed Mater Res A 2005;74(1):23-31.

11. Wang H, He Y, Ratner BD, Jiang S. Modulating cell adhesion and spreading by control of FnIII7-10 orientation on charged self-assembled monolayers (SAMs) of alkanethiolates. J Biomed Mater Res A 2006;77(4):672-8.

12. Schuler M, Owen GR, Hamilton DW, de Wild M, Textor M, Brunette DM, Tosatti SG. Biomimetic modification of titanium dental implant model surfaces using the RGDSP-peptide sequence: a cell morphology study. Biomaterials 2006;27(21):4003-15.

13. Scheideler L, Rupp F, Wendel HP, Sathe S, GeisGerstorfer J. Photocoupling of fibronectin to titanium surfaces influences keratinocyte adhesion, pellicle formation and thrombogenicity. Dent Mater 2007;23(4):469-78.

14. Decher G, Hong JD, Schmitt J. Buildup of ultrathin multilayer films by a self-assembly process: III. Consecutively alternating adsorption of anionic and cationic polyelectrolytes on charged surfaces. Thin Solid Films 1992;210-211:831-5.

15.Ladam G, Schaaf P, Decher G, Voegel J, Cuisinier FJ. Protein adsorption onto auto-assembled polyelectrolyte films. Biomolecular engineering 2002;19(26):273-80.

16. Boudou T, Crouzier T, Ren K, Blin G, Picart C. Multiple functionalities of polyelectrolyte multilayer films: new biomedical applications. Adv Mater 2010;22(4):441-67.

17. Halthur TJ, Claesson PM, Elofsson UM. Immobilization of enamel matrix derivate protein onto polypeptide multilayers. Comparative in situ measurements using ellipsometry, quartz crystal microbalance with dissipation, and dual-polarization interferometry. Langmuir 2006;22 (26):11065-71.
18. Werner S, Huck O, Frisch B, et al. The effect of microstructured surfaces and laminin-derived peptide coatings on soft tissue interactions with titanium dental implants. Biomaterials 2009;30(12):2291-301.

19. Schultz P, Vautier D, Richert L, et al. Polyelectrolyte multilayers functionalized by a synthetic analogue of an anti-inflammatory peptide, alpha-MSH, for coating a tracheal prosthesis. Biomaterials 2005;26(15):2621-30.

20. Cai K, Rechtenbach A, Hao J, Bossert J, Jandt KD. Polysaccharide-protein surface modification of titanium via a layer-by-layer technique: characterization and cell behaviour aspects. Biomaterials 2005;26(30):5960-71.

21. Chua PH, Neoh KG, Kang ET, Wang W. Surface functionalization of titanium with hyaluronic acid/ chitosan polyelectrolyte multilayers and RGD for promoting osteoblast functions and inhibiting bacterial adhesion. Biomaterials 2008;29(10):1412-21.

22. Müller S, Koenig G, Charpiot A, Debry C, Voegel J, Lavalle P, Vautier D. VEGF-Functionalized Polyelectrolyte Multilayers as Proangiogenic Prosthetic Coatings. Adv Funct Mater 2008;18(12):1767-1775.

23.Zhang X, Li Z, Yuan X, Cui Z, Bao H, Li X, Liu Y, Yang X. Cytotoxicity and antibacterial property of titanium alloy coated with silver nanoparticlecontaining polyelectrolyte multilayer. Mater Sci Eng C Mater Biol Appl 2013;33(5):2816-20.

24. Sano K, Shiba K. A hexapeptide motif that electrostatically binds to the surface of titanium. J Am Chem Soc 2003;125(47):14234-5.

25.Liu Y, Mao J, Zhou B, Wei W, Gong S. Peptide aptamers against titanium-based implants identified through phage display. J Mater Sci Mater Med 2010;21(4):1103-7.

26. Estephan E, Dao J, Saab MB, Panayotov I, Martin M, Larroque C, Gergely C, Cuisinier FJ, Levallois B. SVSVGMKPSPRP: a broad range adhesion peptide. Biomed Tech (Berl) 2012;57(6):481-9.

27. Meyers SR, Hamilton PT, Walsh EB, Kenan DJ, Grinstaff MW. Endothelialization of Titanium Surfaces. Adv Mater 2007;19(18):2492-8.

28. Yazici H, Fong H, Wilson B, et al. Biological response on a titanium implant-grade surface functionalized with modular peptides. Acta Biomater 2013;9(2):5341-52.

29. Michael J, Beutner R, Hempel U, Scharnweber D, Worch H, Schwenzer B. Surface modification of titanium-based alloys with bioactive molecules using electrochemically fixed nucleic acids. J Biomed Mater Res B Appl Biomater 2007;80(1):146-155.

30. Michael J, Schönzart L, Israel I, et al. Oligonucleotide-RGD peptide conjugates for surface modification of titanium implants and improvement of osteoblast adhesion. Bioconjugate chemistry 2009;20(4):710-8. 